\title{
Notes
}

\section{Long-distance Anadromous Migration in a Fresh Water Specialist: the Lake Trout (Salvelinus namaycush)}

\author{
Les N. Harris ${ }^{1,5}$, Jean-Sébastien Moore ${ }^{2}$, Christopher G. McDermid ${ }^{1,3}$, and Heidi K. Swanson ${ }^{4}$ \\ ${ }^{1}$ Arctic Aquatic Research Division, Fisheries and Oceans Canada, 501 University Crescent, Winnipeg, Manitoba R3T 2N6 \\ Canada \\ ${ }^{2}$ Institut de Biologie Intégrative et des Systèmes, Université Laval, 1030 Avenue de la Médecine, Québec, Quebec G1V 0A6 \\ Canada \\ ${ }^{3}$ Clayton H. Riddell Faculty of Environment, Earth, and Resources - Environmental Science, University of Manitoba, Winnipeg, \\ Manitoba R3T 2N2 Canada \\ ${ }^{4}$ Department of Biology, University of Waterloo, 200 University Avenue W., Waterloo, Ontario N2L 3G1 Canada \\ ${ }^{5}$ Corresponding author: Les.N.Harris@dfo-mpo.gc.ca
}

Harris, Les N., Jean-Sébastien Moore, Christopher G. McDermid, and Heidi K. Swanson. 2014. Long-distance anadromous migration in a fresh water specialist: the Lake Trout (Salvelinus namaycush). Canadian Field-Naturalist 128(3): 260-264.

The Lake Trout, Salvelinus namaycush, is believed to be one of the most saline intolerant salmonid species, typically completing its life wholly in fresh water. Historical observations and more recent quantitative assessments have shown, however, that in some Arctic populations, Lake Trout can migrate to marine waters (i.e., display anadromy). In the four coastal Arctic populations of Lake Trout where anadromy has been confirmed, migrations to and from marine environments are relatively short (i.e., in the order of a few kilometres). In the Halokvik River on Victoria Island, we captured two anadromous Lake Trout in a weir used jointly for commercial fishing and stock assessment research. Both fish were captured during the fall upstream migration, some $50 \mathrm{~km}$ from their presumed fresh water spawning or overwintering locations. This observation extends the current knowledge regarding the distribution of anadromous populations in this species and suggests that migration to marine habitats can be much longer than previously expected.

Key Words: Lake Trout; Salvelinus namaycush; anadromy; migration; Victoria Island

\section{Introduction}

Migration is a coordinated movement that is evolutionarily advantageous because of the fitness benefits associated with movement to an alternate habitat (Hendry et al. 2004; Binder et al. 2011). Fishes in particular are well known for extraordinary migrations that can be classified based on the aquatic biomes through which they move. Diadromy is a type of migration in which the marine-fresh water boundary is crossed (Binder et al. 2011), and anadromy is a unique type of diadromy, in which fishes hatched in fresh water subsequently migrate to marine habitats for feeding and, eventually, undertake a return migration to fresh water for spawning, overwintering, or both (McDowall 1997, 2007). This life history strategy is exemplified in the salmonid fishes and is typically more prevalent at higher latitudes (Gross et al. 1988; McDowall 2008). Anadromous migrations within this group can be quite remarkable, ranging from thousands of kilometres (Stephenson et al. 2005) to just hundreds of metres (Harris et al. in press).

Among salmonids, Lake Trout (Salvelinus namaycush) are generally thought to be the least tolerant of saltwater conditions (Quinn 2005). Lake Trout were typically believed to be invariably non-anadromous (Hendry et al. 2004), but were recently shown to be able to survive salinities equal to that of full-strength sea water (i.e., 30\%, Hiroi and McCormick 2007). Lake
Trout have been observed sporadically, although rarely, in marine waters (dating back to the 1950s and reviewed in Martin and Olver 1980), and recent data from otolith microchemistry and stable isotope analyses confirm that some coastal Canadian Arctic populations of Lake Trout do make annual migrations to marine environments (Swanson et al. 2010). Among four study populations, $27 \%$ of Lake Trout made annual migrations to the sea, and anadromous Lake Trout were in better condition and had lower concentrations of mercury than fresh water resident Lake Trout (Swanson and Kidd 2009; Swanson et al. 2010). Further study using isotope mixing models found that marine prey items constituted a large proportion $(66 \%)$ of the diet of anadromous Lake Trout (Swanson et al. 2011).

Despite this recent increase in our knowledge of anadromy in the Lake Trout, much remains unknown regarding the distribution of its life history across the northern range of the species and the magnitude of the migrations it undertakes. Where anadromy has been confirmed in Lake Trout, migration distances have been relatively short ( $<3 \mathrm{~km}$, Swanson et al. 2010), suggesting that Lake Trout employing this life history tactic are associated with systems in which the distance to marine waters is short. Here, we describe a case of longdistance migration in anadromous Lake Trout based on observational evidence and capture data accumulated 


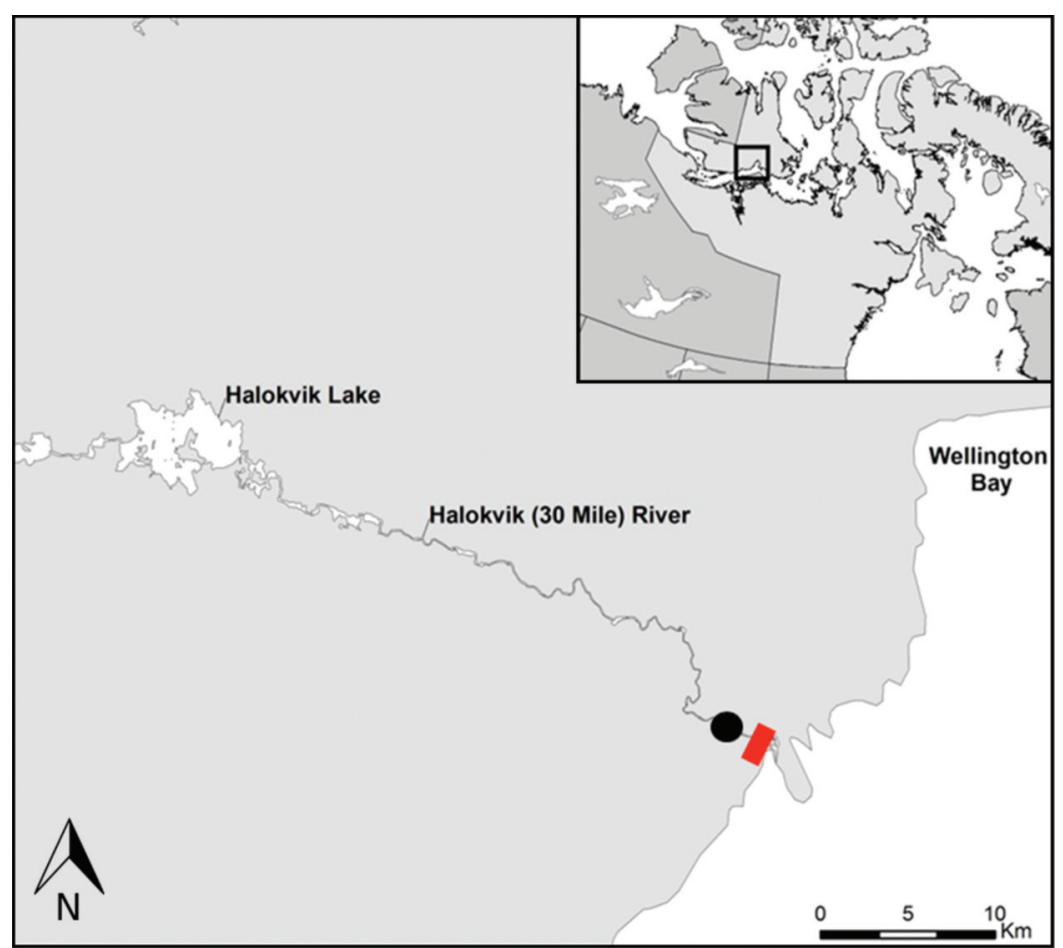

FIGURE 1. Map of the study area showing the location of the Halokvik River (30 Mile) on Victoria Island, Nunavut. Also shown is the location of the weir constructed in 2013 (red rectangle), the position of the acoustic receiver deployed in the river (black circle), and Halokvik Lake where anadromous Lake Trout (Salvelinus namaycush) are presumed to overwinter, some $50 \mathrm{~km}$ from the weir.

from a fisheries weir assessment on the Halokvik River (locally known as 30 Mile), Victoria Island. This river is located in the Canadian Arctic (Figure 1), approximately $80 \mathrm{~km}$ west of the community of Cambridge Bay in Nunavut.

\section{Methods and Observations}

In 2013, Fisheries and Oceans Canada operated a conduit weir on the Halokvik River with the intention of enumerating anadromous Arctic Char (Salvelinus alpinus) migrating upstream. The Halokvik River drains a large system of lakes that flow into the west side of Wellington Bay. The last lake draining into this river, locally known as Halokvik Lake, is located some $50 \mathrm{~km}$ upstream from the ocean and is presumed to be the furthest downstream lake capable of supporting Arctic Char and Lake Trout (J. Hiniliak, Cambridge Bay elder, personal communication, 2013).

The weir, which spanned the entire river (Figure 2) to ensure that all upstream-migrating fish were captured, was designed following the methods outlined by McGowan (1990). It was located near the river mouth, $50 \mathrm{~m}$ from tidal-influenced brackish waters. The weir was operated continually from August 8 to September 10, 2013. In mid-August 2013 (August 16 and 18), two Lake Trout (Figure 3) were captured in the weir as they were most certainly migrating back into fresh water to spawn and/or overwinter, presumably in habitats located $50 \mathrm{~km}$ upstream. Lake Trout 1 was $576 \mathrm{~mm}$ in fork length and weighed $2100 \mathrm{~g}$ and Lake Trout 2 was $531 \mathrm{~mm}$ in length and weighed $1700 \mathrm{~g}$. Both fish were photographed for morphometric analyses, tissue samples were obtained, and the opportunity was taken to implant both with acoustic transmitters (V16 Coded Acoustic Transmitters, VEMCO, Bedford, Nova Scotia).

\section{Discussion}

Although the Lake Trout is often believed to be restricted to fresh water for its entire life cycle, evidence that anadromy may be common in high latitude populations is accumulating. Populations in which anadromy has previously been documented, however, have been found at very short distances from the marine environment (within $3 \mathrm{~km}$, Swanson et al. 2010). Here, we report the capture of two Lake Trout returning from marine waters some $50 \mathrm{~km}$ downstream from the closest lake where overwintering and/or spawning would be possible. It is highly unlikely that these two fish were riverine Lake Trout, given that the Halokvik River freezes solid during winter over most of its course. Furthermore, they were captured in a weir approxi- 


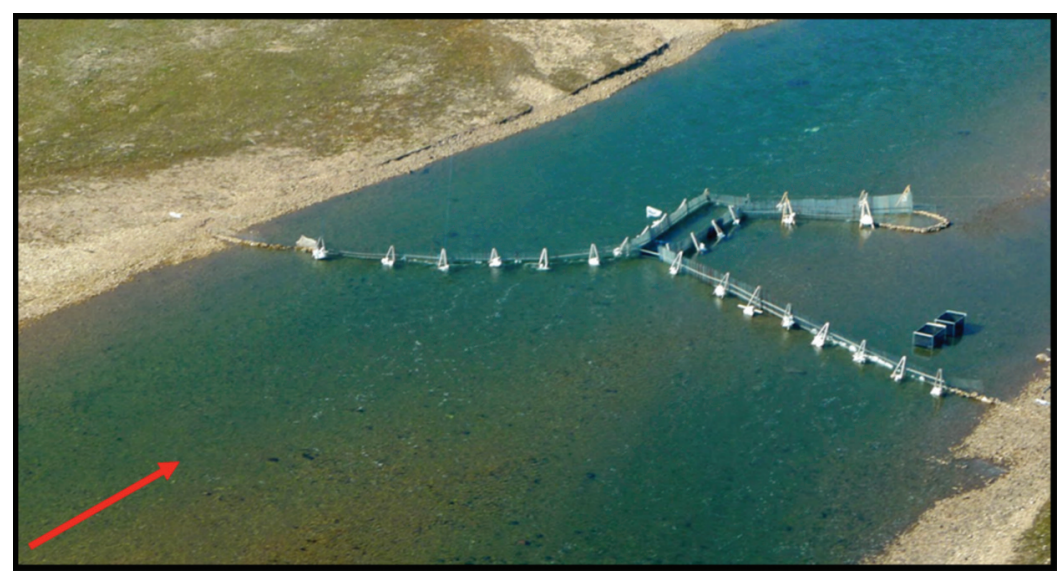

FIGURE 2. Aerial view of the weir across the Halokvik River, Victoria Island, Nunavut, used in 2013 as part of an Arctic Char (Salvelinus alpinus) population assessment. The red arrow indicates the upstream direction of migration. Photo courtesy of Denise LeBleu Images.

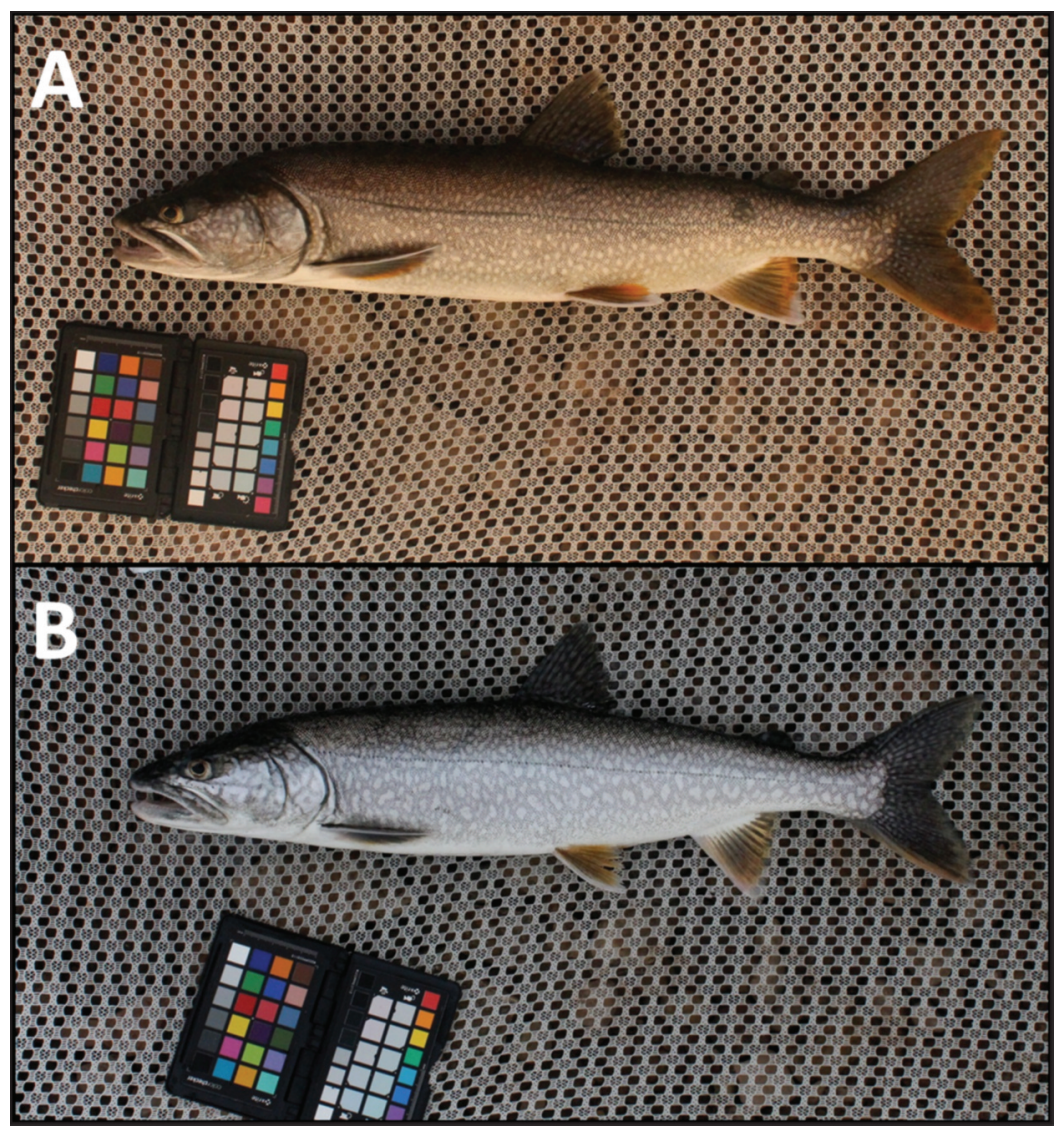

FIGURE 3. The two Lake Trout (Salvelinus namaycush) captured in the Halokvik (30 Mile) River weir, Victoria Island, Nunavut, while migrating from marine waters to spawning and overwintering locations located $50 \mathrm{~km}$ upstream. (A) Lake Trout 1; (B) Lake Trout 2. 
mately $50 \mathrm{~m}$ from tidal influenced waters and, given the energy costs of migration, it is highly unlikely that Lake Trout would migrate $50 \mathrm{~km}$ to exploit fresh water river habitat, which is much less productive than the adjacent brackish and marine habitats. Thus, to our knowledge, this represents the longest documented anadromous migration of Lake Trout, highlighting an unappreciated ability for long-distance migration to and from marine environments in a species that was once thought to be restricted to fresh water.

Local knowledge in the Cambridge Bay region indicates that Lake Trout are sometimes caught in marine waters (B. Nakashook, Cambridge Bay resident, personal communication, 2013). Recently, quantitative evidence of anadromy in Arctic populations of Lake Trout has become available to corroborate this local knowledge (Swanson et al. 2010) and, combined, these pieces of information indicate that anadromy in this species may not be as rare as once assumed. For instance, in Nauyuk Lake, a system located on the mainland of Canada approximately $90 \mathrm{~km}$ southwest of the Halokvik River, $40 \%$ of assessed Lake Trout were classified as anadromous (Swanson et al. 2010). However, marked variation occurred in the proportion of resident versus anadromous fish in other proximate systems (Swanson et al. 2010) and, currently, no fully anadromous populations are known. Further work is thus required to truly understand intra- and interpopulation variation in anadromy in this species and to resolve the specific mechanisms responsible for driving such differences.

Information on the population and biological parameters of anadromous Lake Trout are virtually absent (but see Swanson et al. 2010, 2011). Little is known regarding sizes and ages of anadromous individuals, however, among the four systems located across Dease Strait that were studied by Swanson et al. (2010), age of first migration in Lake Trout varied widely: from 3 to 29 years of age (mean, 13 years). Lake Trout started migrating to sea at a significantly older age on average than sympatric anadromous Arctic Char (5 years of age), and at 13 years of age, first-year migrant Lake Trout were larger (mean $400 \mathrm{~mm}$ fork length) than firstyear migrant Arctic Char (mean 275 mm, Swanson et al. 2010). The anadromous Lake Trout observed in this assessment are within the length ranges reported by Swanson et al. (2010).

Little information is available on the distribution of anadromy in Lake Trout, and further work is required to quantify the prevalence of this life history tactic throughout the northern range of the species. There are, however, reports of anadromous Lake Trout on other Canadian Arctic islands (Manning 1953), and work is ongoing to provide the first assessment on the distribution of anadromy in this species across the coastal Canadian Arctic. Finally, marine habitats used by anadromous Lake Trout are not well characterized. As with other salmonids, they likely prefer brackish coastal waters for feeding on marine invertebrates and fishes (Swanson et al. 2011). Acoustic receivers are currently positioned in the brackish and marine habitats near the mouth of the Halokvik River, and future acoustic telemetry readings may provide the first data on marine habitat use by this species.

Given the considerable distance presumably covered by Lake Trout in our study, marine migrations are not likely opportunistic forays, but rather concerted efforts to access marine habitats. High energetic costs of migration and the potential increased risk of predation (Hendry et al. 2004) mean that the fitness benefits of migrating to marine habitats must be substantial and must outweigh the fitness benefits of remaining in fresh water (Gross 1987). Indeed, oceans are much more productive than fresh water in north-temperate and Arctic environments, and the prevalence of anadromy appears to increase at higher latitudes (McDowall 1987; Gross et al. 1988). Thus, it is likely that anadromous Lake Trout observed in the Halokvik River were accessing marine habitats to take advantage of rich food sources and that this results in higher growth rates, larger size-at age, and greater energy stores (Hendry et al. 2004). This in turn, may result in higher fecundity and overall fitness compared with their fresh water counterparts (Roff 1988). Swanson et al. (2010) found that the diet of anadromous Lake Trout was composed of about $66 \%$ marine-derived prey (based on stable isotope mixing models) and that anadromous Lake Trout were typically in better condition than their fresh water counterparts. This is consistent with the hypothesis that anadromous Lake Trout are migrating to exploit relatively rich marine food sources.

In conclusion, our observations provide novel insight into the distribution of anadromy in Lake Trout populations in the Arctic, now confirming it on Victoria Island, and highlight the potential for long-distance migration in this species as a tactic in a life history that has remained relatively enigmatic.

\section{Acknowledgements}

We thank the Ekalluktutiak Hunters' and Trappers' Organization for help with logistic planning over the course of the field season. Jack (Meyok) Omilgoetok worked on all aspects of the field work and was instrumental in the success of our field season. Jimmy Haniliak helped with tagging at the Halokvik River and Johnny Pedersen assisted with weir construction. We also thank Jimmy Haniliak and Brent Nakashook for providing information on the Halokvik River system. Funding for this project was provided by Fisheries and Oceans Canada (through Nunavut Implementation Funds) and the Nunavut Wildlife Management Board.

Documents Cited (marked * in text)

McGowan, D. K. 1990. Enumeration and biological data from the upstream migration of Arctic Charr, Salvelinus alpinus (L.), in the Cambridge Bay area, Northwest Ter- 
ritories. 1979-1983. Canadian Data Report Fisheries and Aquatic Sciences 811: iv +27 pages.

\section{Literature Cited}

Binder, T. R., S. J. Cooke and, S. G. Hinch. 2011. The Biology of Fish Migration. Pages 1921-1927 in Encyclopedia of Fish Physiology: From Genome to Environment. Edited by A. P. Farrell. Third edition. Academic Press, San Diego, California.

Gross, M. R. 1987. Evolution of diadromy in fishes. American Fisheries Society Symposium 1: 14-25.

Gross, M. R., R. M. Coleman, and R. M. McDowall. 1988. Aquatic productivity and the evolution of diadromous fish migration. Science 239: 1291-1293.

Harris, L. N., J.-S. Moore, P. Galpern, R. F. Tallman, and E. B. Taylor. In press. Geographic influences on fine-scale, hierarchical population structure in northern Canadian populations of anadromous Arctic Char (Salvelinus alpinus). Environmental Biology of Fishes. DOI 10.1007/s10641013-0210-y.

Hendry, A. P., V. Castric, M. T. Kinnison, and T. P. Quin. 2004. The evolution of philopatry and dispersal: homing versus straying in salmonids. Pages 52-59 in Evolution Illuminated: Salmon and Their Relatives. Edited by A.P. Hendry and S. C. Stearns. Oxford University Press, Oxford, U.K.

Hiroi, J., and S. D. McCormick. 2007. Variation in salinity tolerance, gill $\mathrm{Na}+/ \mathrm{K}+$-ATPase, $\mathrm{Na}+/ \mathrm{K}+/ 2 \mathrm{Cl}$ - cotransporter and mitochondria-rich cell distribution in three salmonids Salvelinus namaycush, Salvelinus fontinalis and Salmo salar. Journal of Experimental Biology 210(6): 1015-1024.

Manning, T. H. 1953. Notes on the fish of Banks Island. Arctic 6: 276-277.

Martin, N. V., and C. H. Olver. 1980. The lake charr, Salvelinus namaycush. Pages 205-277 in Charrs, Salmonid Fishes of the Genus Salvelinus. Edited by E. K. Balon. Dr. W. Junk Publishers, Hague, Netherlands.

McDowall, R. M. 1987. The occurrence and distribution of diadromy among fishes. Pages 1-13 in Common strategies of anadromous and catadromous fishes. Edited by M. J. Dadswell, R. J. Klauda, C. M. Moffitt, R. L. Saunders, R.
A. Rulifson, and J. E. Cooper, editors. American Fisheries Society, Symposium 1, Bethesda, Maryland.

McDowall, R. M. 1997. The evolution of diadromy in fishes (revisited) and its place in phylogenetic analysis. Reviews in Fish Biology and Fisheries 7: 443-462.

McDowall, R. M. 2007. On amphidromy, a distinct form of diadromy in aquatic organisms. Fish and Fisheries 8: 1-13.

McDowall, R. M. 2008. Why are so many boreal fresh water fishes anadromous? Confronting 'conventional wisdom'. Fish and Fisheries 9: 208-213.

Quinn, T. P. 2005. The Behavior and Ecology of Pacific salmon and Trout. University of Washington Press, Seattle, Washington. 378 pages.

Roff, D. A. 1988. The evolution of migration and some life history parameters in marine fishes. Environmental Biology of Fishes 22: 133-146

Stephenson, S. A., J. A. Burrows, and J. A Babaluk. 2005. Long-distance migrations by inconnu (Stenodus leucichthys) in the Mackenzie River system. Arctic 58: 21-25.

Swanson, H. K., and K. A. Kidd. 2009. A preliminary investigation on the effects of anadromous Arctic charr (Salvelinus alpinus) on food web structure and nutrient transport in coastal Arctic lakes. Pages 465-483 In Challenges for Diadromous Fishes in a Dynamic Global Environment, Symposium 69. Edited by A. J. Haro, K. L. Smith, R. A. Rulifson, et al., American Fisheries Society, Bethesda, Maryland.

Swanson, H. K., K. A. Kidd, J. A. Babaluk, R. J. Wastle, P. P. Yang, N. M. Halden, and J. D. Reist. 2010. Annual marine migrations in lake trout (Salvelinus namaycush) from the central Canadian Arctic: insights from otolith microchemistry, stable isotope ratios, and comparisons to Arctic charr (S. alpinus). Canadian Journal of Fisheries and Aquatic Sciences 67: 842-853.

Swanson, H. K., K. A. Kidd, and J. D. Reist. 2011. Quantifying importance of marine prey for two partially anadromous fishes. Canadian Journal of Fisheries and Aquatic Sciences 68: 2020-2028.

Received 7 February 2014

Accepted 31 March 2014 